\title{
Shift in the Funding Theory Paradigm: From Newtonian-Positivistic to Critical-Phenomenology
}

\author{
Maria Rio Rita ${ }^{1}$, Sony Heru Priyanto ${ }^{2}$ \\ ${ }^{1}$ Economics and Business Faculty of Satya Wacana Christian University \\ ${ }^{2}$ Agriculture and Business Faculty of Satya Wacana Christian University \\ Jl. Diponegoro 52-60 Salatiga 50711, Indonesia
}

\begin{abstract}
Keywords:

Critical; Funding

Theory;

Newtonian;

Phenomenology;

Positivistic

JEL Classification: B10, G30, G41

Theories about funding have developed rapidly, it was starting from the traditionalrational theory to the behavior-based funding theory, which responds to the gap between the reality and financial theories. The theoretical developments can depict the real condition about financial management involving funding decisions, investment decisions, and dividend policies in an enterprise. These developments and evolution enable financial managers and also entrepreneurs to realistically apply them in their business activities. This research used meta synthesis analysis technique to integrate results from a number of different but inter-related qualitative studies. There has already been a shift in the funding theory paradigm from a Newtonian paradigm which emphasizes positivistic epistemology leading to a Critical paradigm, which places more emphasis on a phenomenological approach to see the reality. This shift has resulted in many changes related to the financial essence, research related to finance, as well as the advantages of the funding or financing theory in a company. A new essence about funding has surfaced, where funding and its benefits can solve company funding problems.
\end{abstract}

Kata Kunci:

Kritis; Teori

Pendanaan;

Newtonian;

Fenomenologi;

Positivistik

\begin{tabular}{l} 
ABSTRAK \\
\hline Teori tentang pendanaan telah mengalami perkembangan, yang dimulai dari teori rasional- \\
tradisional hingga akhirnya menuju ke teori pendanaan berbasis keperilakuan. Adanya \\
perkembangan teori tersebut dapat lebih menggambarkan kondisi riil mengenai manajemen \\
keuangan yang terdiri dari keputusan pendanaan, keputusan investasi, dan kebijakan dividen \\
dalam suatu perusahaan. Perkembangan dan evolusi ini memungkinkan manajer keuangan dan \\
juga pelaku bisnis untukmenerapkan keputusan keuangan secara realistis dalam aktivitas bisnisnya. \\
Penelitian ini menggunakan teknik analisis sintesis meta untuk mengintegrasikan hasil dari \\
sejumlah penelitian kualitatif yang berbeda namun saling terkait. Telah terjadi pergeseran \\
paradigma teori pendanaan dari paradigma Newtonian yang menekankan epistemologi positivistik \\
menuju ke paradigma Kritis, yang lebih memberi penekanan pada pendekatan fenomenologi untuk \\
melihat realita. Pergeseran ini telah menghasilkan banyak perubahan terkait hakekat keuangan, \\
hasil riset di bidang keuangan, serta manfaat penerapan teori keuangan dalam perusahaan. Hakekat \\
baru mengenai keungan khususnya mengenai pendanaan telah muncul, di mana ilmu pendanaan \\
dan pemanfaatannya dapatmemecahkan masalah-masalah pendanaan perusahaan.
\end{tabular}

Corresponding Author:

Maria Rio Rita: Tel./Fax.+62 298321212

E-mail:mriorita011100@gmail.com

ISSN:2443-2687 (Online) ISSN:1410-8089 (Print) 


\section{Jurnal Keuangan dan Perbankan | KEUANGAN}

Vol. 21, No. 4, Oktober 2017: 543-554

The global financial crisis of 2008 is inseparable from the theoretical stagnation as well as the assumptions that were established at that time. The linearity and deterministic assumption using a mathematical formula was unable to explain the existing problems (Van der Burg, 2008). Several financial problems were unable to be explained by a certain theory at a particular time. Then a new theory arose which attempted to explain the reality, resulting in developments in finance. This theory strives to bridge the inequality between the empirical and theoretical level (Van der Burg, 2008). This development is inseparable from a philosophical thinking process. Thinking philosophically means thinking radically and subjectively (Zaprulkhan, 2016). The spirit of research is in the form of repeatedly searching for the truth. This can be conducted whenever it has a radical/ critical thinking pattern towards a finding as well as connects it with research subjectivity. Research subjectivity can originate from researcher recordings, cultural background, and expertise, so that it facilitates doing reflections in research.

Worldviews can determine "what you want to be" and "for what you want to be" in the future. The way one views something or a life viewpoint will influence one's philosophical thinking process. An example is the Newtonian life viewpoint, which is mechanistic-deterministic-reductionistic-atomistic-instrumentalistic-linearistic. This way of thinking will lead to a positivism philosophy, where observation-based truth that is captured by the senses becomes an important measurement. Furthermore, this will result in quantitative research to understand and prove the truth. This viewpoint then is rejected by a post-positivistic viewpoint, which states that it is not enough for truth to be proven by sensory observations, but it has to be proven by other people and other things as well.

Another life viewpoint is a critical approach, which is criticism towards a positivism approach.
All research has to obtain knowledge about "what there is" (das sein) and not "what there should be" (das sollen). In general, a critical approach always looks at a wide context, not only at a particular level but also explores other levels that are involved in an incident. Although this approach is very sharp, it still tends to be moralistic. Besides that, before the presence of Habermans, the epistemology problem was not elaborated directly by the predecessors.

Related with this, philosophical thinking (included in the financial field) keeps developing because humans are free to do self-reflection (Wong, Musa, \& Wong, 2011). There are imbalances in differences in meaning from a particular concept that can be bridged through philosophy. Philosophy acts to understand a certain object, so that when people have the same viewpoint, it will let them understand the reality of that object. Related with philosophical thinking to understand an object from a particular reality including finance, there are 3 philosophical branches that can be learned: (1) ontology, it discusses about what object has been researched by knowledge. It finds out all about something as it is. Ontology examines the "what". This article will explore about what finance is; (2) epistemology, it deals with what process is used to get intrinsic knowledge/truth. Epistemology examines the "how" about knowledge regarding how finance can be born; and (3) axiology, it looks at for what purpose knowledge can be used. It examines how knowledge is applied when it is found at the practical level. Axiology discusses "for what" financial knowledge is used.

Objective of the paper is to describe development of theories about funding, starting from the traditional-rational theory to the behaviorbased funding theory, which responds to the gap between the reality and financial theories. The theoretical developments can depict the real condition about financial management involving fund- 
ing decisions, investment decisions, and dividend policies in an enterprise. These developments and evolution enable entrepreneurs and financial managers to realistically apply them in their business activities. This paper also aims to explain about a shift in the funding theory paradigm from a Newtonian paradigm which emphasizes positivistic epistemology leading to a critical paradigm, which places more emphasis on a phenomenological approach to see the reality. In addition, this paper seeks to explain impact changes related to the financial essence, research related to finance, as well as the advantages of the funding theory in a company.

Previous research was mostly dominated by a positivistic research paradigm, which was then completed and/or replaced with phenomenology research. This shift has resulted in many changes related to the financial essence, research related to finance, as well as the advantages of the funding or financing theory in a company. A new essence about funding has surfaced, where funding and its benefits can solve company funding problems. Below the funding theoretical shifts and developments will be explained, as seen from three philosophical branches ontology, epistemology, and axiology.

\section{METHODS}

This research employed an analysis technique of meta-synthesis. The purpose of meta-synthesis is to integrate results from a number of different but inter-connected qualitative research. This technique has an interpretation, not an aggregate, which is different from the meta-analysis of quantitative studies (Walsh \& Downe, 2005). This method implements the identification of themes in various studies, resulting in a synthesis, while allowing a re-conceptualization across studies and forming a line of argument to represent the results. Argument approach basic is a form of grounded theorizing, which describes a big picture of the whole from studies of its components (Doyle, 2003; Barker et al., 2014).

Some theories such as capital structure theory, behavioral finance, entrepreneurial finance will be reviewed to understand the structure and substance associated with ontology, epistemology, and axiology. Below the funding theoretical shifts and developments will be explained, as seen from 3 philosophical branches ontology, epistemology, and axiology.

\section{RESULTS}

A life viewpoint also influences the funding theory philosophical-ontological thinking process. There has been a shift in the Descartes-Newtonian life viewpoint that has a quantity-only ontology towards a critical life viewpoint ala Popper, which has a quality-idealism ontology. Based on his ontological taxonomy, the funding theory which used to be in a singular form and reflected in a mathematical form has changed to become a pluralistic reality and critical-ideal, which states that reality has a strong connection with ideas, thinking, or spirit, not just about material (Zaprulkhan, 2016). This ontological shift can be explained from developments in the funding theory, starting from the theory by Modigliani and Miller (MM) until the behavioral finance theory.

Every company that conducts its business will certainly do funding activities to fulfill its company's funding needs. Related with this funding, there are 2 primary theories related with this, which are the balancing theory and the pecking order theory. Those 2 theories arose from the appearance of a traditional theory, which explained the influence of equity structure changes in equity or debt towards company value, or company equity costs can be changed through their equity structure changes. Modigliani \& Miller (1958) argued that in a perfect equity market condition and 


\section{Jurnal Keuangan dan Perbankan | KEUANGAN}

Vol. 21, No. 4, Oktober 2017: 543-554

without taxation, then whether funding decisions will use debt or its own equity is no longer relevant and has no effect on the prosperity of company owners. In other words, company value will always remain the same in different equity structure conditions, whether a company uses debt (levered firm) or whether a company does not have debt (unlevered firm). This pessimistic argument is known with the MM 1 proposition. MM then proposed proposition II in a tax-free condition, by explaining that the total equity costs cannot be reduced when debt is substituted with its own equity, even though the debt equity costs are visibly cheaper than the equity itself. MM confirmed that the two effects offset each other, so that the company value and total company equity costs are the same when using debt (Ross et al., 2002a).

Later, Modigliani \& Miller (1963) adjusted the previous opinion which stated that an equity structure does not have an effect on company value by entering a taxation element. The MM 1 proposition (with taxation) explains that the value of a company which has debt will be higher compared with a company that does not have debt. This is due to the advantages from reducing the tax burden (tax shield), which is imposed on company revenue. Increasing the company value through reducing taxes will be greater whenever the company increases its debt ratio. As a result, clean revenue which is the right of stockholders will increase with the assumption of ceteris paribus. The MM 2 proposition (with taxation) states that equity costs will increase in line with an increase in debt. Stockholders face high risks from an increase in company debt, so that it will require a higher level of return also. The MM 2 proposition with this taxation coincides with the MM 2 proposition without taxation.

Next, Kraus \& Litzenberger (1973) proposed a hypothesis about the balance that should be achieved between bankruptcy resulting from debt with the advantages of tax savings when changing the equity structure. According to Miller (1977), an increase in the debt ratio is only able to increase company value until a certain level, which is referred to as the optimal equity structure (static trade-off theory). Increasing the debt can potentially cause conflict between the owner and creditor, because the creditor faces the potential of loss. It is clear that an increase in agency costs will also decelerate the increase in company value, so that the company can no longer add to its debt (Asri, 2013).

Besides the MM theory, there is also the pecking order theory, which has a different assumption with the previous balancing theories. This theory, which was initiated by Myers (1984), deals with a company's preference in accessing alternative funding sources. A company prefers to use internal resources than external funding, which is obtained from withheld profit that is produced from company operational activities. If external funding is needed, then a company will first start from the safest securities, which is the lowest risk debt, then go to higher risk debt, hybrid securities like conversion obligation, preferential stocks, and the last regular stocks. The pecking order theory does not indicate an equity structure target. A financial manager does not consider the optimal debt level.

There is a positive correlation between the level of company debt and profitability. A company which has a low profit expectation tends to take a low level of debt. A low reduction interest on loans is needed to offset the size of profits before taxation. Besides that, if a company adds to its debt, it will increase its potential financial distress. Meanwhile, a company which is more successful tends to take greater debt. Rational investors will prefer companies that have higher debt. This means that investors see debt as a positive signal from company value. Whenever this management strategy succeeds, a company's stock prices will increase due to investors' responses (Ross, Westerfield, \& Jordan, 2002b). 
In the 1980s, the behavioral finance theory emerged. This theory evolved from concern by researchers who viewed that an efficient market assumption does not coincide with the reality (Kahneman \& Tversky, 1979; Shefrin \& Statman, 1994a; Shiller, 1995; Shleifer, 2000). In a traditional financial framework, rational investors (smart money) will consistently monitor the market to capture opportunities to acquire abnormal returns. In a traditional viewpoint, market inefficiency is small, tends to be temporary, and is unpredictable. A traditional viewpoint states that a company manager can trust stock market prices and does not experience mispricing, as long as the information that is published is available (Shefrin, 2007). Meanwhile, according to the behaviorist viewpoint, in certain situations an inefficient condition tends to be bigger and last longer, which is called an anomaly (Shefrin, 2007). In fact, investors in conducting investments do not only use estimates of their investment prospects, but the psychological factor also influences their decision making in determining their investments (Shefrin, 2002). Investors design their portfolios not only based on portfolio theories but also involve the psychological aspect in it. The returns expected by investors are not only determined by mispricing but also by considering risks. These risks can reduce aggressive actions by investors when they are engaged in transactions (limits of arbitrage phenomenon) (Shefrin, 2007). Behavioral finance theory handles the inconsistency through explanations based on human behavior, whether individual or group.

Furthermore, when discussing equity structure decisions, the behavioral approach uses the same thinking framework as the traditional approach, but it combines it with the biased effect (behavioral element). According to the traditional approach, a manager makes financial decisions through maximizing the adjusted present value
(APV), maximizing the total net present value (NPV), and taking advantage of the funding from debt. However, actually this funding is chosen because there is a manager perception effect that will cause mispricing by the market. Therefore, actually the behavioral approach also accommodates traditional elements in explaining funding decisions (Shefrin, 2007). This infers that in financial problems, besides its own funds, there is also the behavioral factor (psychological) like emotions, a ratio that influences decision making regarding finance. There are at least three important factors in behavioral finance that influence making financial decisions, heuristic, framing, and emotions (Baker \& Nofsinger, 2010).

In the 1990s, the entrepreneurial finance (EF) theory emerged. This theory combined the financial theory with the entrepreneurial theory (Leach \& Melicher, 2010). This theory surfaced because the previous financial theory was unable to explain about funding problems in the early stages of a company's establishment. This concept differs from corporate finance, where corporate finance separates funding decisions and investment decisions. But for entrepreneurial finance, it integrates the 2 decisions into one activity, it does not only discuss the funding aspect, but it also covers the company, starting from the company's plans, marketing production, human resources, and risks (Coleman, 2004; Rogers \& Makonnen, 2008; Paré et al., 2009). Meanwhile, Leach \& Melicher (2011) stated that entrepreneurial finance focuses on business financial management, which is based on the entrepreneurial process like acquiring and developing opportunities, fulfilling needed assets, meeting human capital needs, fulfilling financial resources, as well as managing and developing operations with the primary goal of creating meaning. Figure 1 is a taxonomy-ontology of financing theory. 
Jurnal Keuangan dan Perbankan | KEUANGAN

Vol. 21, No. 4, Oktober 2017: 543-554

The first milestone of modern thought of capital structure:

Modigliani \& Miller (1958): funding decisions does not affect the firm's value in a state of perfect market.

Balancing Theories \& Trade off Theory:
Modigliani \& Miller (1963); funding decisions affect the
firm's value in a state of perfect market, when there are
corporate tax and personal tax.
Kraus \& Litzenberg (1973): the exchange between the
benefits of debt with cost arising from increased debt.
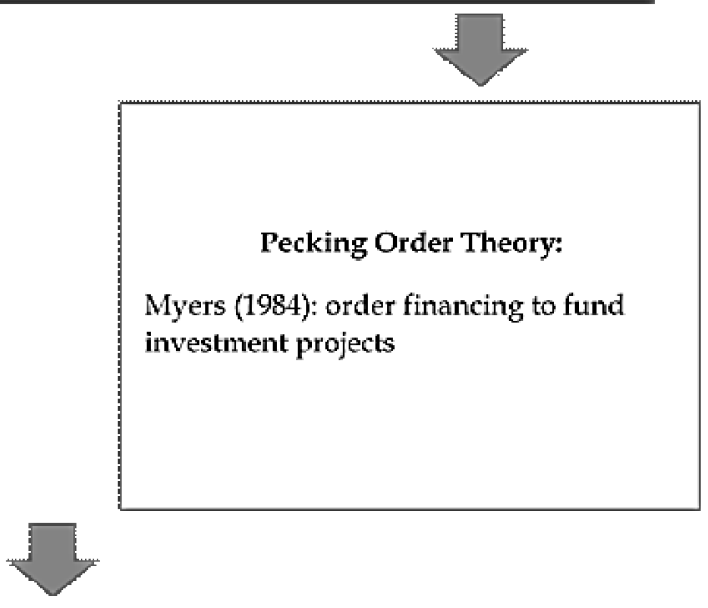

\section{Behhaviơral Finance Theoory:}

Kahneman \& Tversky (1979); Shefrin \& Statman (1984); Shiller (1995); Shleifer (2000): individual's psychological aspects influence on financial decisions. These aspects include cognitive emotional response and social psychology.

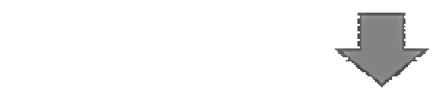

\section{Entrepreneurial Finance (EF) Theory:}

This theory integrates two decisions in one activity, not just on funding aspect, but also the business aspect (Roger \& Makonnen, 2014). This theory is an intersection between finance theory and entrepreneurship theory.

Figure 1. Taxonomy-Ontology of Financing Theory Source: Developed for this study (2017)

\section{DISCUSSION}

Epistemology covers characteristic of the knowledge and finds how to verify the truth. In understanding this terminology, epistemology is related with problems that cover: (1) philosophy, as a branch of philosophy that tries to find the substance and truth of knowledge; (2) methods, as a method, the purpose is to lead humans to obtain knowledge; and (3) system, as a system, the goal is to obtain the reality of the truth from the knowledge itself. Thus, epistemology is a branch of philosophy that examines in-depth and radically about the origin of knowledge, structure, methods, and knowledge validity (Zaprulkhan, 2016).

Related with epistemology to obtain the truth, there are positivistic-quantitative and phe- 


\section{Shift in the Funding Theory Paradigm: From Newtonian-Positivistic to Critical-Phenomenology}

Maria Rio Rita \& Sony Heru Priyanto

nomenological-qualitative paradigms. Positivistic is also often referred to as logical positivism, which believes that philosophy must follow the same rigorousness as science. In general, believers of a positivism understanding have a strong interest in science and have a skeptical attitude towards religious knowledge and metaphysical things. They are convinced that all knowledge must be based on logical inference that is based on clear facts, so that followers of this understanding support realism, materialism, naturalism, and empiricism theories. It states that a statement can be considered as having meaning if and only if the statement can be verified empirically. A consequence of this opinion is that all forms of discourse that cannot be proven empirically, including ethics and problems of beauty, do not have any meaning, so that they are classified in the metaphysics field.

Critics of this understanding believe that the basis that is used by logical positivism is not manifested in a consistent form. For instance, a principle about a theory about meaning that can be proven as stated above cannot be proven empirically. There is the problem of bias in an empirical fact, where not all theories can be proven in different realities and different times. Based on these weaknesses, an understanding of phenomenology arose.

Phenomenology means a description about a phenomenon or something that is symptomatic. This method strives to obtain a true understanding to acquire its own reality. Phenomenology adheres to or believes that all thinking and depictions in human awareness ideas refer to something, a thing, or a condition like this, meaning thinking and depictions which are directed or about something that is considered intentional. As a scholarly research effort, phenomenology strives to clarify the subtleties of phenomena gathering, including financial phenomena. A basic problem of phenomenology philosophy is how it can obtain or achieve knowledge that is right, legitimate, and absolute. The way it works or through a phenomenological approach is a human try to analyze the intentionality structures (awareness characteristic about something), in how it is parallel with a person psychoanalytically in uncovering unaware emotions. Next is to find a theory or hypothesis that is related to solve problems that are connected with the same data set. That kind of a theory or hypothesis is then tested for its validity in the subsequent empirical research. In the phenomenology that becomes its object is facts, symptoms, items, or realities that are symptomatic.

To find the truth about a financial-funding reality, most researchers use a positivistic paradigm by emphasizing a mathematical financial and empirical model (Ardalan, 2012). This paradigm is mostly used when evaluating stocks, calculating equity costs, and determining a combination of debt and equity itself. This paradigm can even be used for a financial model, using several assumptions that are greatly determined in a quantitative-deterministic way. For instance, in a capital structure, there are 2 approaches used in the financial theory, the traditional approach and the Modigliani and Miller approach. It seems that to operate those models, they reduce the reality by applying assumptions, so that the model can be implemented. This approach causes skepticism, including in its own origin because it is considered as being inappropriate with the reality. Therefore, a new theory surfaced about equity structure in a perfect equity market and there is taxation, as stated by Modigliani and Miller. This model also still uses the same paradigm only different with its assumption, so that it is closer with the real condition. There is also no exception with the trade-off theory (static trade-off theory), where this theory combines the MM equity structure theory with including bankruptcy costs and agency costs, which indicates that there is a trade-off between tax savings from debt with bankruptcy costs, as well as the pecking order theory, where 


\section{Jurnal Keuangan dan Perbankan | KEUANGAN}

Vol. 21, No. 4, Oktober 2017: 543-554

funding needs are determined by investment needs, so that a company does not target its equity structure.

The last 2 theories are still in one doctrine or paradigm with the previous theory that uses a positivistic deterministic empirism paradigm to obtain knowledge and solve financial problems. Of course, the epistemology paradigm above causes doubt for other scholars, which then reached its peak during the world financial crisis of 1998, where the models were unable to overcome the reality problem and were far from what really happened. In response to that problem, a new epistemology surfaced that tried to explain and solve the problem that occurred in financial reality, which then gave rise to a new substance in the form of the behavioral finance theory.

One of the assumptions that are based on the financial theories is concerning investor rationality. According to academicians, this assumption originates from classic and neo-classic literature. When a researcher searches for knowledge about human behavior, here related to investors and financial managers, the researcher cannot only use a positivistic deterministic paradigm. There are phenomena that cannot be explained with this paradigm. The paradigm that is then developed in an epistemology perspective is the critical-interpretive paradigm. In the behavioral finance theory, human behavior is discussed like perception, motivation, attitude, learning, and personality. To understand this problem, a critical interpretive phenomenology paradigm needs to be used, so that the reality of human behavior can be known and explained.

Behavioral financial research has been conducted by Gombola \& Marciukaityte (2007), who researched about managerial over-optimism and the choice between debt and equity financing. Duclos (2015), who researched about the psychology of investment behavior. Xiao (2011), who researched about funding, high-tech SMEs, business development stages (start-up, early stage, and later stage), and financial strategies using the financial life cycle theory. They researched with radical and interpretive structuralist epistemology, where this approach emphasizes in an objective and subjective approach to see various aspects, not only finance but also human behavioral dynamics with subjectivity to cover it, including a process to evaluate and make decisions related with funding.

Theories, knowledge, technology, and ethical evaluations are all evaluated to see whether they are beneficial or not. In operating a company, there are many problems related with finance like how to make optimal business activities, how to obtain funding needs for efficient investments, how to maintain an optimal resource composition, is it better for a company to use foreign equity or its own equity, and are there company payment decisions that influence company value.

Financial managers will try to do various things like maximize the current company value, the financial theory enables a financial manager to calculate the company value. The financial theory also facilitates financial managers to calculate risks to make stockholders earn a profit. This means that the financial theory has axiology for managers and investors. Financial managers are able to fulfill their funding needs, both from inside and outside the company, whether the funding needs will be fulfilled from debt or their own equity. Financial managers will be able to calculate their equity costs to meet their funding needs.

MM Theory. By having this theory, financial managers will use debt, even though they have enough of their own equity that comes from profit withheld or other assets. This is because there are benefits by reducing the tax shield that is imposed on company revenue. Increasing company value through reducing taxes will be bigger whenever the company adds to its debt ratio. In spite of this, this theory does not calculate bankruptcy costs, 
so that there is a tendency for a company to acquire as much debt as possible, which can result in financial difficulties and bankruptcy.

Balancing Theory (Static Trade-off Theory). This theory facilitates financial managers to calculate the optimal equity structure for a company. The presence of this theory makes financial managers not just add debt when there is a funding need for the company. This can occur because an increase in debt has the potential to cause conflict between the owner and creditors, because creditors face potential losses. It is clear that an increase in agency costs also reduces the increase in company value, so that the company will not add any more debt (Asri, 2013).

Pecking Order Theory. The emergence of this theory facilitates financial managers to make a list of priorities in funding, because this theory discusses company preferences in accessing alternative funding sources. By having this theory, it adds to financial managers' knowledge to use internal funding sources instead of external funding sources that are obtained from profit that is withheld and produced from earlier company operational activities and then debt if needed. If external funding is needed, then the company will first start from the safest securities, which is the lowest risk debt, then go to riskier debt, hybrid securities like conversion obligation, preferential stocks, and finally regular stocks.

Signaling Theory. This theory can be useful for managers and investors in operating their enterprise. To increase company value, usually financial managers will increase the size of their debt. This theory will help investors to get a signal that the company will increase its debt, meaning that it is an expansive and positive effort to buy company stocks because the debt principle is tax deductible. This theory will enable financial managers to increase stock prices resulting from a positive response by investors. Despite this, there is no guarantee that a manager is honest in making funding decisions. If this happens, then the stock price evaluation will be far from its actual value.

In a traditional finance framework, there is a reality that rational investors will constantly monitor the market to acquire opportunities to obtain abnormal returns. As a result, it will trigger arbitrage, which is when investors buy securities that are underpriced and the other way around will sell securities that are overpriced. Furthermore, this arbitrage can eliminate the chance to get abnormal returns for market actors (Shefrin \& Statman, 1994b; Shefrin, 2002).

Behavioral Finance Theory. This theory can explain that in making funding decisions, it is necessary to calculate the psychological aspect of investors and financial managers, because in certain situations inefficient conditions tend to be bigger and last longer, which is referred to as an anomaly (Shefrin, 2002). Investor behavior is no longer completely like that explained by the traditional financial theory. As a result, bigger funds can enter and funds can be smaller than predicted, keeping in mind that there is a psychological aspect from investors. This makes financial managers pay more attention to the psychological aspect of investors.

Entrepreneurial Finance Theory. The emergence of this theory facilitates financial managers to obtain funds when a new company has just been established, to get funding during shake-ups and a shift in its lifecycle. Besides that, this theory also enables financial managers to see and capture opportunities as well as know how to try to obtain and utilize available funding sources to actualize an effort.

In the financial theory, if there is no psychological aspect, the effect will be disadvantageous for the company and investors. Managers who are too trusting in financing decisions and company value will tend to increase their debt, in order that they can receive funds that can also be used for other purposes. When investors have managerial moral hazards, they will also provide debt with- 


\section{Jurnal Keuangan dan Perbankan | KEUANGAN}

Vol. 21, No. 4, Oktober 2017: 543-554

out considering the risks faced, because investors have a conflict of interest with themselves. A manager who has too much faith in one's ability and underestimates financial difficulty costs when operating a business will have a negative effect on the company value (Fairchild, 2009). This negative effect will be stronger when a company uses more debt than what it needs. This means that if a manager is too confident in one's ability regarding debt, it will not have a clear effect for the company value. Meanwhile, a positive effect will arise when the company uses less debt than its funding needs.

\section{CONCLUSION AND SUGGESTIONS}

\section{Conclusion}

Weisskopf (1979) stated that there has been a shift from the Newton paradigm to the Heisenbergian paradigm motivated by the desire to counteract worry that is certainly produced by the human condition from risks and uncertainties about the future. This condition also occurs in financial reality. The reality about finance is inseparable with the problems of ontology, epistemology, and axiology. There has already been a shift in financial philosophy, where understanding financial reality has shifted not only as a form, starting from the traditional-rational theory until behavioralbased financial theories. Borrowing a term from Spremann (2009), there has already been a change from the old paradigm to a new financial paradigm in response to changes within the financial industry. It started from the traditional financial paradigm (old finance), which only struggled to discuss the funding issue and investment projects, then surfaced the neoclassic approach, modern portfolio theory and optional price determination, empirical research in the equity market, corporate finance, until strategic corporate finance.

Looking at the development of financial theory, there is a shift in the financial theory para- digm, from a Newtonian paradigm that emphasizes a positivistic epistemology to a critical paradigm that emphasizes more in a phenomenological approach to see reality. The Newtonian paradigm is a mechanistic-deterministic-reductionisticatomistic-instrumentalistic-linearistic world viewpoint, which places humans as a part (partial), as the center of something overall (Capra, 2000). The complex reality with interconnectedness is viewed as only a group of atomic beams. The reality puzzle should be taken apart one by one. Then from observations, choose which ones should be connected and then quantified. This viewpoint actually, besides failing in capturing the reality completely or holistically, this viewpoint, which is then known with the Cartesian-Newtonian paradigm, then contributes to a complex and multidimensional crisis, including the financial crises of 1998 and 2008.

A weakness of this viewpoint is it then led to a new viewpoint, the Heisenberg viewpoint, where looking at an object's reality cannot be separated from the subject, the object cannot be released from the subject. The subject is the participant, not just an observer (non-participant), so that the subject partakes in determining the reality. Similarly, with modern cosmology, which considers the cosmos as being unaware, meaningless, and non-organic in developing new physics, such as bootstrap physics, it proves that the cosmos is not inanimate but rather alive. In finance, then a theory was devised about behavioral finance and entrepreneurial finance, where finance cannot only be determined from a financial perspective, but it can also be determined by other people.

\section{Suggestions}

Business reality is constantly changing and complex, so to improve business performance is not only related to financial matters. Financial issues are not just about money, but there are be- 


\section{Shift in the Funding Theory Paradigm: From Newtonian-Positivistic to Critical-Phenomenology}

Maria Rio Rita \& Sony Heru Priyanto

havioral elements in it. Conceptions of behavioral finance have been widely expressed, but how it can be operationalized in research remains unclear. Therefore, it is necessary to conduct further research by making concepts, measurements and mechanisms when researchers conduct phenomenological research in the field of finance. For example, how to make research on finance by involving latent variables with ratio and non-ratio indicators. From a practical point of view, in measuring financial performance, not only based on deterministic measurements such as financial ratios, it is necessary to apply measurement such as behavioral-based performance measurement. When formulating the premise, not only linearly, but need to be formulated in accordance with the existing reality. For example, in predicting the effect of funding on performance, internal capital, debt and external capital does not necessarily affect business performance. It needs to be mediated with entrepreneurship and business processes and also moderated by the business and economic environment. Simple linear and deterministic models need to be reviewed by developing a more holistic and integrative financial model that can describe the existing reality.

Previous research was mostly dominated by a positivistic research paradigm, which was then completed and/or replaced with phenomenology research. This research has produced new concepts regarding finance-funding, financial knowledge, as well as the advantages of this knowledge in solving company financial problems.

\section{REFERENCES}

Ardalan, K. (2012). On the role of paradigms in finance. Farnham: Ashgate Publishing, Ltd.

Asri, M. (2013). Keuangan Keperilakuan. Yogyakarta: BPFE.
Barker, A. B., Nair, R. D., Lincoln, N. B., \& Hunt, N. (2014). Social identity in people with multiple sclerosis: a meta-synthesis of qualitative research. Social Care and Neurodisability, 5(4), 256-267.

Baker, H. K., \& Nofsinger, J. R. (2010). Behavioral finance: an overview. Behavioral Finance: Investors, Corporations, and Markets, 1-21.

Capra, F. (2000). Titik Balik Peradaban: Sains, Masyarakat, dan Kebangkitan Kebudayaan. Yogyakarta: Yayasan Bentang Budaya.

Coleman, S. (2004). Variations on a theme: teaching entrepreneurial finance. Journal of Entrepreneurship Education, 7, 73-81.

Doyle, L. H. (2003). Synthesis through meta-ethnography: paradoxes, enhancements, and possibilities. Qualitative Research, 3(3), 321-344.

Duclos, R. (2015). The psychology of investment behavior: (De) biasing financial decision-making one graph at a time. Journal of Consumer Psychology, 25(2), 317-325.

Fairchild. (2009). Managerial overconfidence, moral hazard problems, and excessive life cycle debt sensitivity. Investment Management and Financial Innovations, 6(3), 1-27.

Gombola, M., \& Marciukaityte, D. (2007). Managerial overoptimism and the choice between debt and equity financing. The Journal of Behavioral Finance, $8(4), 225-235$.

Kahneman, D., \& Tversky, A. (1979). Prospect theory: an analysis of decision under risk. Econometrica, 47(2), 263-292.

Kraus, A., \& Litzenberger, R. H. (1973). A state-preference model of optimal financial leverage. Journal of $\mathrm{Fi}$ nance, 28(4), 911-922.

Leach, J. C., \& Melicher, R. W. (2010). Entrepreneurial finance. Fourth Edition. South Western: Cengage Learning.

Leach, J. C., \& Meliche, R. W. (2011). Entrepreneurial finance. Fifth Edition. South Western: Cengage Learning.

Miller, M. H. (1977). Debt and taxes. The Journal of Finance, 32(2), 261-275. 


\section{Jurnal Keuangan dan Perbankan | KEUANGAN}

Vol. 21, No. 4, Oktober 2017: 543-554

Modigliani, F., \& Miller, M. H. (1958). Association the cost of capital, corporation finance, and the theory of investment. The American Economic Review, 48(3), 261-297.

Modigliani, F., \& Miller, M. H. (1963). Corporate income taxes and the cost of capital: a correction. The American Economic Review, 53(3), 433-443.

Myers, S. C. (1984). The capital structure puzzle. Journal of Finance, 57(3), 575-592.

Paré, J. L., Rédis, J., \& Sahut, J. M. (2009). The development of entrepreneurial finance research. International Journal of Business, 14(4), 283-290.

Rogers, S., \& Makonnen, R. (2008). Entrepreneurial finance. New York: McGraw-Hill Professional Publishing.

Ross, S. A., Westerfield, R., Jaffe, J. F., \& Roberts, G. S. (2002a). Corporate finance. Seventh Edition. New York: McGraw-Hill/Irwin.

Ross, S. A., Westerfield, R., \& Jordan, B. D. (2002b). Fundamentals of Corporate Finance. New York: Tata McGraw-Hill Education.

Shefrin, H. (2002). Beyond greed and fear: Understanding behavioral finance and the psychology of investing. Oxford: Oxford University Press on Demand.

Shefrin, H. (2007). Behavioral corporation finance: decisions that create value. New York: McGraw-Hill.

Shefrin, H., \& Statman, M. (1994a). Behavioral capital asset pricing theory. Journal of Financial and Quantitative Analysis, 29(3), 323-349.

Shefrin, H., \& Statman, M. (1994b). Behavioral capital asset pricing theory. Journal of Financial and Quantitative Analysis, 29(3), 323-349.
Shiller, R. J. (1995). Conversation, information, and herd behavior. The American Economic Review, 85(2), 181185.

Shleifer, A. (2000). Inefficient markets: an introduction to behavioural finance. Oxford: OUP Oxford.

Spremann, K. (2009). Old and new financial paradigms. Current Challenges for Corporate Finance, 7-26.

Van der Burg, J. (2013). Paradigm shift in finance theory. http:/ / www.researchgate.net/publication/ 280447273. Retrieved: 3 July 2017.

Van der Burg, W. (2008). Understanding the gap between theory and practice. http://ssrn.com/abstract=1096108. Retrieved: 18 July 2017.

Walsh, D., \& Downe, S. (2005). Meta synthesis method for qualitative research: a literature review. Journal of advanced nursing, 50(2), 204-211.

Weisskopf, T. E. (1979). Marxian crisis theory and the rate of profit in the postwar US economy. Cambridge Journal of Economics, 3(4), 341-378.

Wong, K. M., Musa, G., \& Wong, E. S. K. (2011). A review of philosophical assumptions in management research. African Journal of Business Management, 5(29), 11546-11550.

Xiao, L. (2011). Financing high-tech smes in China: a three-stage model of business development. Entrepreneurship and Regional Development, 23(3-4), 217234.

Zaprulkhan. (2016). Filsafat ilmu: sebuah analisis kontemporer. Jakarta: Rajawali Pers. 